\title{
DZIERŻAWA OBWODU LOWIECKIEGO W ASPEKCIE TRANSLATOLOGICZNYM
}

\author{
Paulina NOWAK-KORCZ, dr \\ Podyplomwe Studia dla Kandydatów na Tłumaczy Pzrzysięgłych \\ Instytut Językoznawstwa, Wydział Neofilologii \\ Uniwersytet im. Adama Mickiewicza \\ Al. Niepodległości 4, 61-874 Poznań \\ paulina.nowak@gmail.com
}

\begin{abstract}
Abstrakt: Artykuł jest poświęcony zagadnieniu umowy dzierżawy obwodu łowieckiego w aspekcie translatologicznym polsko-francuskim i francusko-polskim. Autorka dokonuje charakterystyki instytucji dzierżawy obwodu łowieckiego $\mathrm{w}$ prawie polskim i francuskim, wymienia typowe klauzule umowne właściwe dla obydwu umów oraz wskazuje podobieństwa i różnice na poziomie makro- i mikrostruktury analizowanych umów dzierżawy istotne w punktu widzenia przekładu. W badaniach, autorka posługuje się metodą porównawczą tekstów paralelnych (Delisle 2006) oraz bazuje na modelu pragmatycznego tłumaczenia terminów prawnych (Kierzkowska 2002) opartym na teorii skoposu Vermeera (1978, 2001). Autorka zaprezentowała także przykładowe tłumaczenie umowy dzierżawy obwodu łowieckiego oraz bail de chasse.
\end{abstract}

Słowa kluczowe: tłumaczenie, umowa dzierżawy, obwód łowiecki, łowiectwo

\section{BAIL DE CHASSE DANS LA PERSPECTIVE DE TRADUCTION}

Résumé: Le présent article aborde le problème de contrat de bail de chasse dans la perspective de traduction. L'auteur caractérise le bail de chasse dans le système juridique polonais et français, énumère les clauses typiques de contrat de bail de chasse en langue polonaise et française ainsi que montre les ressemblances et les différences sur le niveau de macrostructure et microstructure de textes analysés, importantes de point de vue de traduction. Dans les recherches l'auteur applique la méthode de comparaison de textes parallèles (Delisle 2006) et le modèle de traduction pragmatique de termes juridiques proposé par Kierzkowska (2002) basé sur la théorie du skopos de Vermeer $(1978,2001)$. Dans l'article l'auteur propose aussi l'exemple de traduction de contrat de bail de chasse en langue polonaise et française.

Mots clés: traduction, contrat de bail, lot de chasse, chasse

\section{HUNTING DISTRICT LEASE IN TRANSLATION}

\begin{abstract}
This paper deals with Hunting District Lease Agreement in Polish-French and FrenchPolish translation. The author characterizes the institution of Hunting District Lease in the Polish and French legal systems, distinguishes the typical contractual clauses in both languages Polish and presents the similarities and the differences on the level of the macro- and microstructure of the analyzed texts of agreements which are very important from the translative perspective. In her research the author applies the method of parallel text comparison (Delisle 2006) and the model of pragmatic translation of legal terms described by Kierzkowska (2002) based on the skopos theory of translation by Vermeer $(1978,2001)$. The examples of translation of the Hunting District Lease Agreement in Polish and French are also presented.
\end{abstract}

Key words: translation, contract of lease, hunting district, hunting 


\section{Wstęp}

Niniejszy artykuł dotyczy problematyki związanej z przekładem umów dzierżawy, a konkretnie polskich i francuskich umów dzierżawy obwodu łowieckiego. Wspomniana dzierżawa jest obecnie często praktykowaną formą dzierżawy zarówno w Polsce jak i we Francji, a w konsekwencji coraz częściej poddawana jest przekładowi na język polski i francuski. Dlatego też, celem niniejszego artykułu jest przybliżenie przykładowych rozwiązań translatorskich związanych z przekładem wspomnianych umów.

Dzierżawa obwodu łowieckiego (jako dzierżawa prawa) stanowi specyficzny rodzaj dzierżawy. Wydzierżawiający nie jest właścicielem gruntu, na którego obszarze istnieją warunki do prowadzenia łowiectwa, będącego przedmiotem dzierżawy. W wyniku zawarcia umowy, nie może zatem dojść do przeniesienia posiadania gruntu na dzierżawcę. Ponadto, „w stosunkach dzierżawy praw nie występuje akcent ekonomiczny, gdyż koło łowieckie jako dzierżawca nie wytwarza pożytków, a pozyskuje je wskutek upolowania zwierzyny stanowiącej własność osoby trzeciej, to jest Skarbu Państwa" (Szachułowicz 2002, 51). Podstawowym celem dzierżawy łowieckiej zarówno w Polsce jak i we Francji jest zachowanie i ochrona określonych gatunków zwierząt, czynnik ekonomiczny ma znaczenie drugorzędne.

$\mathrm{Z}$ punktu widzenia praktyki tłumaczeniowej ważna jest znajomość makrostruktury oraz mikrostruktury ${ }^{1}$ thumaczonego tekstu umowy poddawanej przekładowi tzn. wyrażeń wprowadzających poszczególne części umowy, typowych zwrotów czy sformułowań charakterystycznych dla danego gatunku umowy oraz znajomość języka umowy na poziomie mikrostruktur tekstu np.: zdań, syntagm oraz wyrazów (por. Jopek-Bosiacka 2006, 91). Kolejną istotną kwestią jest także znajomość terminologii oraz dziedziny, do której należy tłumaczony tekst, a w tym przypadku prawa zobowiązań umownych oraz prawa łowieckiego. Wiedza na temat powyższych elementów niewątpliwie ułatwia tłumaczenie i pozwala uniknąć błędów w przekładzie.

W niniejszym artykule wykorzystano metodę porównawczą tekstów paralelnych (Delisle 2006, 97) ${ }^{2}$ oraz bazowano na modelu pragmatycznego thumaczenia terminów prawnych (Kierzkowska 2002), opartym na teorii skoposu Vermeera (1978, 2001).

W pierwszej części artykułu omówiono aspekty prawne dotyczące instytucji dzierżawy łowieckiej. Następnie krótko scharakteryzowano strukturę tekstu analizowanych umów, $\mathrm{z}$ wyszczególnieniem typowych klauzul umownych. Zaprezentowano także przykładowe rozwiązania translatorskie $\mathrm{w}$ postaci thumaczenia

\footnotetext{
${ }^{1}$ Makrostruktura reprezentuje temat globalny tekstu, a także obejmuje globalną organizację treści. Natomiast mikrostruktura stanowi rodzaj schematu segmentów tekstowych, którym przypisuje się skonwencjonalizowane kategorie tekstowe (...)" (Lizisowa 2013, 32).

${ }^{2}$ Tekst w języku docelowym, należący do tego samego gatunku co tekst wyjściowy i/lub traktujący o tej samej problematyce, z którego thumacz może wynotować terminy, wyrażenia i wiadomości tematyczne, których potrzebuje aby dokonać tłumaczenia. (...) teksty paralelne są dla tłumacza źródłem właściwych słów, terminologii, informacji o charakterze stylistycznym, mogą one również ułatwić mu zrozumienie tekstu wyjściowego".
} 


\section{Comparative Legilinguistics 17/2014}

polskiej umowy dzierżawy obwodu łowieckiego na język francuski oraz odpowiadającej jej francuskiej umowy dzierżawy bail de chasse na język polski.

\section{Dzierżawa obwodu łowieckiego w prawie polskim}

Dzierżawa obwodu łowieckiego to dzierżawa obszaru gruntu o ciągłej powierzchni, zamkniętej jego granicami, nie mniejszego niż trzy tysiące hektarów, na którego obszarze istnieją warunki do prowadzenia łowiectwa (art. 23 ustawy łowieckiej z dnia 13 października 1995 roku $^{3}$ - cytowana dalej jako u.ł.). Umowa dzierżawy obwodu łowieckiego regulowana jest przepisami zawartymi w powyższej ustawie (a konkretnie postanowieniami rozdziału 5, zatytułowanego: Obwody łowieckie, w art. 23-31 u.ł.), oraz w oparciu o rozporządzenie z dnia 28 marca 1997 roku ${ }^{4}$. Oczywiście do dzierżawy obwodu łowieckiego mają również zastosowanie przepisy Kodeksu cywilnego dotyczące dzierżawy praw (art. 709 k.c.).

Według art. 29 u.ł. obwody łowieckie są wydzierżawiane kołom łowieckim na wniosek Polskiego Związku Łowieckiego ${ }^{5}$, po zasięgnięciu opinii zarządu gminy oraz właściwej izby rolniczej. Koła łowieckie posiadają osobowość prawną. Stanowią one podstawowe ogniwa organizacyjne w Polskim Związku Łowieckim, służące realizacji celów i zadań łowiectwa.

Obwody łowieckie leśne ${ }^{6}$, bez względu na to czyją własność stanowią lasy i grunty leśne, są wydzierżawiane przez dyrektora regionalnej dyrekcji Państwowego Gospodarstwa Leśnego Lasy Państwowe, natomiast obszary łowieckie polne ${ }^{7}$ są wydzierżawiane przez starostę, wykonującego zadanie z zakresu administracji rządowej (art. 29 ust. 1, pkt. 1 i 2 u.ł.). „Przedmiotem dzierżawy nie jest rzecz, lecz prawo do prowadzenia gospodarki łowieckiej, w tym również prawo do polowania" (Szachułowicz 2002, 50). W dzierżawie obwodu łowieckiego, rozumianej jako dzierżawa prawa, nie zachodzi konieczna przesłanka wydania rzeczy (jak przy dzierżawie rzeczy, gdzie przedmiot musi być wydany dzierżawcy), lecz wystarczy

\footnotetext{
${ }^{3}$ Ustawa z dnia 13 października 1995. Prawo łowieckie. (Dz. U. z 2002r. Nr 42, poz. 372 i Nr 113, poz. 984 oraz z 2004r. $\mathrm{Nr} 92$, poz. 880, Nr 172, poz. 1802 , Nr 173, poz. 1808)

${ }^{4}$ Rozporządzenie Ministra Ochrony Środowiska i Zasobów Leśnych z dnia 28 marca 1997 r. w sprawie szczegółowych zasad wydzierżawiania obwodów łowieckich i ustalania czynszu dzierżawnego, udziału przez dzierżawców obwodów łowieckich w kosztach ochrony lasu przed zwierzyną oraz wzoru umowy dzierżawnej. (Dz. U. z dnia 11 kwietnia 1997 r.)

${ }^{5}$ Polski Związek Łowiecki (PZŁ) - Polski Związek Łowiecki jest zrzeszeniem osób fizycznych i prawnych (kół łowieckich), które - w myśl ustawy z dnia 13 października 1995 r. - czynnie uczestniczą w ochronie rozwoju populacji zwierząt łownych oraz działają na rzecz ochrony przyrody. Zrzeszenie istnieje od roku 1923 (nazywało się wówczas: Polski Związek Stowarzyszeń Łowieckich) i już w okresie międzywojennym było jedynym reprezentantem myśliwych w naszym kraju. W roku 1928 polscy myśliwi byli współzałożycielem istniejącej do chwili obecnej, Międzynarodowej Rady Łowiectwa i Ochrony Zwierzyny (CIC). Organizacja ta skupiając przedstawicieli około 140 państw świata jest największym forum myśliwych. Od roku 1994 PZŁ jest także członkiem innej bardzo licznej międzynarodowej organizacji łowieckiej Federacji Związków Łowieckich Państw Unii Europejskiej. (http://www.pzlow.pl/palio/html.run? Instance=www.pzlow.pl\&_PageID=181\&_CheckSum=1407643472-16.02.2010).

${ }^{\overline{6}}$ Obwód leśny to obszar, w którym grunty leśne stanowią co najmniej $40 \%$ ogólnej powierzchni tego obszaru.

${ }^{7}$ Obwód polny to obszar, w którym grunty leśne stanowią mniej niż 40\% ogólnej powierzchni obwodu.
} 
udostępnienie przedmiotu dzierżawy w ściśle określonych terminach nie objętych ochroną zwierząt łownych. Dzierżawa obwodu łowieckiego „,...) obejmuje obszary przydatne wyłącznie dla gospodarki łowieckiej, z oderwaniem się od nieruchomości, zarówno $\mathrm{w}$ sensie prawnym, jak i geodezyjnym, przy uwzględnieniu natomiast kryteriów ekologicznych, opartych na nauce o strukturze i funkcjonowaniu przyrody" (Szachułowicz 2002, 50). Tworzenie tych obszarów następuje w drodze rozporządzenia wojewody, $\mathrm{z}$ pominięciem udziału osób posiadających uprawnienia do gruntów wchodzących w skład obwodu. Wojewoda, tworząc obwody łowieckie ma jedynie obowiązek zasięgnięcia opinii dyrektora regionalnej dyrekcji Państwowego Gospodarstwa Leśnego Lasy Państwowe i Polskiego Związku Lowieckiego, oraz właściwej izby rolniczej.

\subsection{Czynsz dzierżawny}

W Polsce, czynsz dzierżawny przysługuje wydzierżawiającemu, który nie wydaje własnego przedmiotu dzierżawy, ale udostępnia cudze obszary dla celów realizacji gospodarki łowieckiej. Czynsz dzierżawny jest określony normatywnie i jest ustalany w zależności od kategorii obwodu łowieckiego. Jego wysokość oblicza się mnożąc ilość hektarów obszaru dzierżawionego obwodu łowieckiego przez równowartość pieniężną żyta, przy zastosowaniu wskaźnika przeliczeniowego (który nie może być wyższy niż 0,07q żyta za 1 hektar) (art. 30. ust. 2a u.1.). Czynsz dzierżawny może być podwyższony o udział w kosztach ochrony lasu przed zwierzyną, poniesionych w roku, w którym nie zrealizowany został roczny plan łowiecki. Może on również zostać pomniejszony w przypadku udokumentowania poniesionych przez dzierżawcę wydatków na poprawę warunków bytowania zwierzyny w obwodzie łowieckim ( 33 , pkt. 2-3 rozporządzenia).

\subsection{Zawarcie umowy dzierżawy}

Jeśli chodzi o zasady zawierania umowy dzierżawy obwodów łowieckich, koła łowieckie, mimo iż mają osobowość prawną, nie mają legitymacji do składania wniosku o dzierżawę, a inicjatywę w tym zakresie ustawodawca przyznał wyłącznie Polskiemu Związkowi Łowieckiemu. Wniosek o wydzierżawienie obwodu łowieckiego powinien zatem zawierać: informacje dotyczące: koła łowieckiego, liczby członków, siedziby, osób uprawnionych do jego reprezentacji. Wydzierżawienie następuje na podstawie umowy sporządzonej na piśmie, według określonego wzoru stanowiącego załącznik do rozporządzenia z dnia 28 marca 1997 roku. Artykuł 29 u.ł. określa szczegółowo jakie elementy powinna zawierać umowa dzierżawy obwodu łowieckiego.

Polska umowa dzierżawy obwodu łowieckiego jest typową umową adhezyjną, gdzie jedną ze stron jest organ administracji publicznej, natomiast druga strona (koło łowieckie), nie ma możliwości negocjowania warunków określonych we wzorze umowy. Wobec tego, zawarcie umowy dokonuje się poprzez przystąpienie koła łowieckiego do warunków przedstawionych przez organ administracji.

Polska umowa dzierżawy obwodu łowieckiego zawierana jest $\mathrm{z}$ dniem 1 kwietnia, a kończy się w dniu 31 marca, po upływie 10 lat. Czas trwania umowy jest związany z okresem wieloletnich łowieckich planów hodowlanych, dlatego dzierżawa 


\section{Comparative Legilinguistics 17/2014}

obwodu łowieckiego nie może trwać krócej niż 10 lat. Po tym terminie, dzierżawcy przysługuje pierwszeństwo do przedłużenia umowy (art. 29 ust. 2 u.ł.).

\section{Bail de chasse w prawie francuskim}

Francuskim odpowiednikiem polskiej umowy dzierżawy obwodu łowieckiego jest bail de chasse, która, podobnie jak w Polsce, jest dzierżawą prawa do polowania na danym terenie, czyli w obwodzie łowieckim (lot, zone de chasse). Do dzierżawy obwodu łowieckiego we Francji stosuje się ogólne przepisy dotyczące najmu i dzierżawy rzeczy (louage de choses) zawarte we francuskim kodeksie cywilnym (art. 1709 C. civ.). Instytucja ta została bowiem wyłączona $\mathrm{z}$ regulacji pozakodeksowych dotyczących dzierżaw (art. L 415-10 C. rur.). Francuska umowa dzierżawy obwodu łowieckiego może być zawarta między właścicielem danego terenu a osobą fizyczną lub stowarzyszeniem myśliwych (association des chasseurs).

Należy w tym miejscu podkreślić, że francuskie prawo łowieckie nie ma jednoznacznej kodeksowej definicji. Jedyna sformułowana i zapisana w Kodeksie rolnym (art. 222-1 C. rur.) definicja: „nikt nie ma prawa polować na terenie będącym cudzą własnością bez zgody właściciela lub innej uprawnionej przez niego osoby" (tłum. Nowak-Korcz), jest przestarzała.

Regulacje prawa łowieckiego obowiązujące we Francji zawarte są w ustawach, z których najstarsza sięga czasów Rewolucji (ustawa z pluviose'a V roku Republiki). „Duża ich część wynika z ustawy policyjnej z maja 1844 r., wielokrotnie zmienianej, a także z licznych odrębnych przepisów, które nakładają się na istniejące regulacje od 1960 roku. Dekret z listopada 1989 r. skodyfikował quasi-całość tego zespołu norm jako obowiązujące prawo (...) " (Stec 2009, 123). W dekrecie tym, prawo łowieckie zostało włączone do zespołu przepisów prawnych odnoszących się do ochrony przyrody $^{9}$. Wiele regulacji o charakterze ustawowym, niestety, nie doczekało się jeszcze kodyfikacji.

„Dla pewnej liczby regulacji dotyczących przede wszystkim prowadzenia polowań, minister ustala ogólne ramy, zgodne ze zobowiązaniami międzynarodowymi i europejskimi, które stosowane są we Francji" (Stec 2009, 123). Następnie, na podstawie tych ram, prefekci jako przedstawiciele władzy wykonawczej w departamentach, określają przepisy, które stosowane są w poszczególnych departamentach przez „stowarzyszenia myśliwych w departamentach” (associations départamentales des chasseurs).

Istotne znaczenie dla prawa łowieckiego miał fakt unieważnienia „wyłącznego przywileju polowania" (privilège exclusif de la chasse). Został on zniesiony dekretem z dnia 11 sierpnia $1789^{10}$ roku, w czasach Rewolucji Francuskiej. Postanowieniami tego dekretu ustanowiono przede wszystkim, że prawo polowania (prawo łowieckie) (droit de chasse) we Francji, jest związane z prawem własności (droit de propriété). Tym samym, nastąpiło ścisłe rozróżnienie między prawem łowieckim, które jest prawem rzeczowym, a prawem do polowania (droit de chasser), które jest uprawnieniem

\footnotetext{
8 „nul n'a la faculté de chasser sur la propriété d'autrui sans le consentement du propriétaire ou de ses ayants droit." (art. L. 222-1 C. rur).

${ }^{9}$ Loi n ${ }^{\circ} 76-629$ du 10 juillet 1976 relative à la protection de la nature

${ }^{10}$ Décret du 11 août 1789 relatif à l'abolition des privilèges.
} 
osobistym. „W definicję prawa interweniowało stopniowo przede wszystkim orzecznictwo sądowe i obecnie można uważać, że prawo łowieckie jest elementem prawa własności. Stanowi ono jedno z praw użytkowania prawa własności i uważane jest za prawo rzeczowe dotyczące nieruchomości. Prawo łowieckie połączone z prawem własności należy do właściciela terytorium, kimkolwiek by był (państwo, społeczność miejscowa, osoba prywatna, itp.). Prawa tego, ogólnie rzecz biorąc, można użyczyć osobie trzeciej. Jeśli chodzi o prawo do polowania, to jest ono udzielane wybranej osobie przez właściciela lub przez posiadacza prawa łowieckiego. W pewnych wypadkach może mieć charakter obligatoryjny: rolnik i tak dzierżawiący użytkowaną ziemię od właściciela korzysta obligatoryjnie (tylko on sam) z prawa polowania na dzierżawionych ziemiach, a właściciel nie może się temu sprzeciwić (...). Prawo polowania jest we wszystkich wypadkach prawem ściśle osobistym, związanym z osobą, która z niego korzysta, w odróżnieniu od prawa łowieckiego związanego z przedmiotem i z własnością, której dotyczy" (Stec 2009, 126).

$\mathrm{Na}$ uwagę zasługują regulacje prawne dotyczące organizacji terytoriów łowieckich we Francji. Francuskie prawo powszechne (droit commun) nie precyzuje minimalnego rozmiaru obszaru pozwalającego na prowadzenie polowania na jakimś terytorium. Istnieją jednak pewne złagodzenia tej zasady, związane albo z zarządzaniem dzikimi gatunkami albo $\mathrm{z}$ organizacją terytorium łowieckiego. Zarządzanie pewną liczbą dzikich gatunków wiąże się z koniecznością uzyskania tzw. ,planu odstrzału” (plan du tir), w oparciu o który ustalana jest liczba zwierząt, które mogą być pozyskane na danym terytorium. Powierzchnia tego terytorium jest różna $\mathrm{w}$ zależności od pozyskiwanego gatunku, a najczęściej dokonuje się zgrupowania terenów łowieckich, aby możliwe było polowanie przez stowarzyszenia.

„O ile organizacja terytoriów jest swobodna na $2 / 3$ powierzchni Francji, nie jest taka na pozostałej trzeciej części" (Stec 2009, 126). Istotne jest w tym względzie prawo łowieckie w departamentach Alsace-Moselle, Bas-Rhin i Haut-Rhin, gdzie prawo to na obszarach mniejszych niż 25 ha należy do gminy na mocy ustawy z 1881 roku, przyjętej podczas okupacji niemieckiej między 1870 a 1918 rokiem. Gmina tworzy terytoria o powierzchni co najmniej 200 ha w całości, przyznaje te rewiry łowieckie i zarządza finansowo łowiectwem na rachunek właścicieli. Poza tym, w 29 departamentach francuskich obowiązuje ustawa $\mathrm{z}$ dnia 10 lipca $1964^{11}$, tzw. ustawa Verdeille, która powstała w oparciu o założenia cytowanej powyżej ustawy z $1881 \mathrm{r}$. Ustawa Verdeille poruszyła kwestię jednej z form stowarzyszenia myśliwskiego ACCA (Association communale de chasse agrée) działającego na podstawie ustawy z 1901 roku, oraz wprowadziła obowiązkowe zgrupowanie terytoriów i praw łowieckich (regroupement obligatoire des parcelles) dla własności ziemskich o powierzchni od 20 do 60 ha. Niemniej jednak to zgrupowanie własności ziemskich nie odbywa się ,pod protektoratem" gmin (jak to miało miejsce w przypadku departamentu Alsace-Moselle), ale w nieco odmienny sposób, czyli poprzez przeniesienie praw łowieckich należących do myśliwych oraz właścicieli ziemskich (będących myśliwymi lub nie) na stowarzyszenie ACCA w danej gminie. Celem tej ustawy jest ochrona praw myśliwych

\footnotetext{
${ }^{11}$ La loi $\mathrm{n}^{\circ}$ 64-696 du 10 juillet 1964 relative à l'organisation des associations communales et intercommunales de chasse agréées (dite "loi Verdeille» au nom de son rapporteur au Sénat, complétée par le décret $\mathrm{n}^{\circ}$ 66-747 du 6 octobre 1966, texte codifiés sous les articles L.422-2 à L.422-24 et R. 422-1 à 422-81 du code de l'environnement).
} 


\section{Comparative Legilinguistics 17/2014}

lokalnych poprzez zgrupowanie terytoriów w celu lepszego zarządzania tymi terenami. W zamian za przeniesienie tych praw na stowarzyszenia, właściciele mogą wstąpić do stowarzyszenia i polować na całym, utworzonym w ten sposób, terenie. „Ponadto właściciele, nie będący myśliwymi, mają prawo, nawet jeśli nie należą do stowarzyszenia, uczestniczyć w jego walnym zebraniu z prawem głosowania i mogą być wybierani do rady administracyjnej, a zatem mogą wpływać na życie ACCA. (...) Terytoria są zarządzane bądź bezpośrednio przez właścicieli, bądź przez myśliwych, jeśli prawo łowieckie jest przeniesione na stowarzyszenie lub wydzierżawione mu" (Stec 2009, 127).

Opisane powyżej zbiorowe zarządzanie obszarami łowieckimi we Francji jest zdecydowanie najbardziej rozpowszechnione i, chociaż nie jest to forma obligatoryjna, staje się ona coraz częściej regułą. Niemniej jednak, pozostaje nadal bardzo duża część terenów we Francji, gdzie brak jest jakiejkolwiek organizacji, tzw. terytoria polowania gromadzkiego (nadal szeroko reprezentowane na południu Francji). „Jeśli chodzi o własność prywatną państwa lub zbiorowości publicznych, będących właścicielami dóbr łownych, to szczegółowe reguły zarządzania są niemal systematycznie włączane do umowy dzierżawy i winny być ściśle przestrzegane pod karą unieważnienia umowy i wypłacenia odszkodowań" (Stec 2009, 127).

\subsection{Czynsz dzierżawny (prix du bail, loyer)}

Czynsz dzierżawny we Francji (prix du bail) może być uiszczany w pieniądzu lub w formie świadczeń takich jak: zalesianie (repeuplement), zagospodarowywanie obszaru łowieckiego (aménagement), itp. W przypadku czynszu pieniężnego, umowa dzierżawy jest z reguły opatrzona klauzulą rewizyjną (clause de révision), bądź klauzulą indeksacyjną (clause d'indexation), która przewiduje zmianę wysokości czynszu dzierżawnego w zależności od zmian cen zboża. Czynsz pieniężny ustalany jest także w oparciu o cenę dziczyzny proponowaną przez urzędowy wykaz cen targowych (rynkowych) $^{12}$.

\subsection{Zawarcie umowy dzierżawy (conclusion du bail de chasse)}

We Francji, odmiennie niż w Polsce, nie ma konkretnych wymogów i reguł dotyczących sporządzania oraz samej formy umowy dzierżawy obwodu łowieckiego. Może ona być zawarta zarówno w formie pisemnej jak i ustnej, niemniej jednak większość umów sporządzana jest na piśmie. Zastosowanie mają przepisy francuskiego kodeksu cywilnego dotyczące najmu i dzierżawy. Umowa dzierżawy w formie aktu notarialnego (acte notarié) jest obowiązkowo sporządzana w przypadku dzierżaw obwodów na okres dłuższy niż 12 lat. Najczęściej stosowaną w praktyce formą umowy dzierżawy obwodu łowieckiego jest zwykła umowa pisemna (acte sous seing privé). Strony dysponują w zasadzie pełną swobodą przy zawieraniu tej umowy, niemniej jednak musi ona być zgodna $\mathrm{z}$ obowiązującym porządkiem publicznym (ordre public). W umowie muszą się znaleźć obowiązkowo klauzule, które warunkują ważność umowy. Są to klauzule określające: obszar, na którym ma się odbywać polowanie

\footnotetext{
${ }^{12}$ Mercuriale des Halles de Rungis (Ministère de l'Agriculture - Services de Nouvelles du Marché - 202, rue de la tour Centra 124-94566 Rungis Cedex)
} 
(désignation du territoire de chasse), czas trwania umowy dzierżawy obwodu łowieckiego (durée du bail de chasse), czynsz dzierżawny (prix du bail, loyer). $\mathrm{W}$ praktyce, strony zawierające francuską umowę dzierżawy obwodu łowieckiego korzystają bardzo często z wzorów proponowanych przez prefektów dla danych departamentów.

We Francji umowa dzierżawy obwodu łowieckiego zawierana jest $\mathrm{z}$ reguły na okres 3 lat i może być odnawiana poprzez tzw.: tacite reconduction, czyli dorozumiane przedłużenie umowy, co trzy lata, chyba że jedna ze stron wypowie dzierżawę listem poleconym za potwierdzeniem odbioru co najmniej 6 miesięcy przed przewidzianym terminem zakończenia umowy. Niemniej jednak, wypowiedzenie to musi nastąpić przed zamknięciem danego sezonu polowania (fermeture de la chasse), aby następna umowa mogła zostać zawarta z początkiem kolejnego roku łowieckiego (année cynégetique).

\section{Struktura tekstu umów dzierżawy obwodu lowieckiego a przekład}

Jak słusznie zauważają Kielar i Michałowska (1994, 7) „tekst umowy jest tak zorganizowany, by najlepiej służyć prezentacji woli stron". Umowa precyzuje więc kolejno podmioty będące jej stronami, wskazuje przedmiot umowy, określa prawa i obowiązki stron, reguluje istotne kwestie związane $\mathrm{z}$ wykonaniem umowy oraz często odsyła do dodatkowych dokumentów zawierających szczegółowe informacje dotyczące przedmiotu umowy.

Dla potrzeb niniejszego artykułu, w analizowanych umowach można wyróżnić następujące części (por. Damasiewicz 2005; Olczyk 2006; ):

(i) elementy wstępne (nagłówek, preambuła umowy),

(ii) treść umowy (prawa i obowiązki umawiających się stron),

(iii) elementy finalne (informacje o egzemplarzach i odpisach umowy, podpisy stron).

Do najistotniejszych klauzul umownych, występujących w ramach wyżej wymienionych części umów można z kolei zaliczyć, między innymi:

(i) klauzule dotyczące oznaczenia przedmiotu umowy, klauzule dotyczące numeru i powierzchni obwodu łowieckiego, klauzule dotyczące obszaru gruntów leśnych i polnych wchodzących w skład obwodu łowieckiego, klauzule dotyczące kategorii obwodu łowieckiego;

(ii) klauzule dotyczące czasu obowiązywania i zakończenia umowy (klauzule dotyczące czasu trwania umowy, klauzule dotyczące zakończenia umowy rozwiązania i wypowiedzenia, klauzule dotyczące przedłużenia i odnowienia umowy);

(iii) klauzule dotyczące czynszu dzierżawnego (klauzule dotyczące ustalenia wysokości czynszu za dzierżawę obwodu łowieckiego, klauzule dotyczące terminu i sposobu płatności czynszu);

(iv) klauzule dotyczące zasad zastosowania odstrzału zastępczego;

(v) klauzule dotyczące oddawania przedmiotu dzierżawy w poddzierżawę i do bezpłatnego używania osobie trzeciej;

(vi) klauzule dotyczące egzemplarzy i odpisów umowy. 
W umowie francuskiej pojawiają się ponadto klauzule, których nie ma w analizowanej umowie polskiej, np.:

(i) klauzula dotycząca szczegółowych warunków wykonywania polowania;

(ii) klauzula dotycząca eliminowania gatunków szkodliwych;

(iii) klauzula dotycząca szkód łowieckich.

W poniższej części artykułu zaprezentowano przykładowe tłumaczenie polskiej i francuskiej umowy dzierżawy obwodu łowieckiego.

Przykład 1. Tłumaczenie polskiej umowy dzierżawy obwodu łowieckiego na język francuski

\section{UMOWA DZIERŻAWY OBWODU LOWIECKIEGO [BAIL DE CHASSE]}

W dniu 10.09.1997 w Koninie pomiędzy Wojewodą Konińskim zwanym dalej "Wydzierżawiającym", a Kołem Łowieckim Nr 15 „Gęgawa” w Słupnie reprezentowanym przez Jana X - Prezesa Kola Ireneusza Y - Lowczego Kola,

zwanym dalej "Dzierżawcą", została zawarta umowa treści następującej:

[Le 10/09/1997, à Konin, entre les soussignés, SLOT : Voïévode de Konin, TLOT

: Préfet de Konin,

ci-après dénommé « Le bailleur » d'une part,

et

le club de chasse $\mathbf{N}^{\mathbf{0}} \mathbf{1 5}$ «Gęgawa» à Słupno, représenté par Jan X - Président du club de chasse

ci-après dénommé « Le preneur », d'autre part

Ireneusz Y - Responsable de la chasse, Il a été convenu et exposé ce qui suit :]

$\S 1$.

Wydzierżawiający oddaje, a Dzierżawca bierze w dzierżawę obwód łowiecki nr $10 \mathrm{w}$ województwie konińskim utworzony przez Wojewodę Konińskiego, stanowiący obszar gruntów leśnych o powierzchni 254 ha i gruntów polnych o powierzchni 3.993 ha (słownie łącznie hektarów: cztery tysiące dwieście czterdzieści siedem), jako obwód: bardzo dobry / dobry / średni / słaby / bardzo słaby/.

[Le bailleur donne à bail et le preneur prend à bail le terrain de chasse $\mathbf{n}^{\mathbf{0}} \mathbf{1 0}$ situé dans la SLOT : voïvodie de Konin, TLOT : région de Konin, créé par le Voḯvode de Konin et constitué de la surface boisée de $\mathbf{2 5 4}$ ha et de la surface de plaine de 3.993 ha (au total en toutes lettres : quatre mille deux cent quarante-sept hectares) en tant que terrain de chasse: très ben, bon, moyen, faible, très faible.]

\section{$\S 2$.}

Umowa została zawarta na okres od dnia zawarcia niniejszej umowy do 31 marca $2007 \mathrm{r}$.

[Le présent bail de chasse est conclu pour la période commençant le jour de la conclusion du présent contrat et finissant le 31 mars 2007.]

$\S 3$.

1. Dzierżawca zobowiązuje się do płacenia w okresie trwania umowy czynszu dzierżawnego w wysokości ustalonej według zasad określonych w rozporządzeniu Ministra Ochrony Środowiska, Zasobów Naturalnych i Leśnictwa z dnia 28 marca 1997 r. w sprawie szczegółowych zasad wydzierżawiania obwodów łowieckich 
i ustalania czynszu dzierżawnego, udziału przez dzierżawców obwodów łowieckich w kosztach ochrony lasu przed zwierzyną oraz wzoru umowy dzierżawnej (Dz. U. Nr 34, poz. 210).

[1. Le preneur s'oblige à payer pendant la durée du contrat le loyer au montant défini selon les dispositions du règlement du Ministre de l'Environnement, des Ressources Naturelles et de la Sylviculture du 28 mars 1997 relatif aux conditions particulières concernant le bail de terrains de chasse et la fixation du loyer, la participation des preneurs de terrains de chasse aux frais de la protection de la forêt contre le gibier ainsi que le modèle de contrat de bail de chasse (publié au Journal des Lois no 34, texte 210).]

2. W pierwszym roku trwania umowy czynsz dzierżawny wynosi 450 zł (słownie złotych: czterysta pięćdziesiąt złotych), płatne na konto WBK o/Konin nr 10981189-3467-123-0987-01

[2. Pendant la première année de la durée du contrat le montant du loyer sera fixé à $450 \mathrm{zl}$ (en toutes lettres: quatre cent cinquante zlotys) payable au compte bancaire WBK succursale de Konin $\mathbf{n}^{\circ}$ 1098-1189-3467-123-0987-01]

3. W każdym następnym roku umowy Wydzierżawiający zawiadamia Dzierżawcę o wysokości czynszu dzierżawnego w terminie do 31 marca.

[3. Chaque année subséquente le bailleur informe le preneur du montant du loyer jusqu'au 31 mars.]

4. Dzierżawca płaci czynsz dzierżawny jednorazowo do 31 maja każdego roku dzierżawy.

[4. Le preneur paye le loyer une seule fois jusqu'au 31 mai chaque année de la durée du bail.]

Dzierżawca obowiązany jest do prowadzenia racjonalnej gospodarki łowieckiej w oparciu o wieloletni plan hodowlany i roczny plan łowiecki, współdziałania $\mathrm{z}$ właściwym nadleśnictwem w ustalaniu stanów zwierząt łownych, zatrudnienia strażnika łowieckiego.

[Le preneur s'oblige à assurer une gestion cynégétique rationnelle respectant le plan d'élevage pluriannuel et le plan annuel de chasse, ainsi qu'à coopérer avec l'Administration des Forêts compétente pour déterminer l'effectif de gibier chassable, à engager un garde de chasse.]

\section{$\S 5$.}

1. W przypadku nierealizowania przez dzierżawcę rocznego planu łowieckiego pozyskania łosi, jeleni, danieli, saren, nadleśniczy Państwowego Gospodarstwa Leśnego Lasy Państwowe wydaje postanowienie o zastosowaniu odstrzału zastępczego.

[1. En cas de non-réalisation par le preneur du plan annuel de chasse précisant le prélèvement des élans, des cerfs ainsi que des chevreuils, l'administrateur SLOT : d'Exploitation Nationale des Forêts ; TLOT : d'Office National des Forêts prend la décision d'application du plan d'abattage supplémentaire.]

2.W postanowieniu o zastosowaniu odstrzału zastępczego wskazuje: gatunki i liczbę zwierząt, termin i sposób wykonania, zobowiązanego do pokrycia kosztów organizacji, osoby, które dokonają odstrzału.

[2. Dans la décision d'application du plan d'abattage supplémentaire il indique: les espèces et le nombre de gibier, le délai et le mode de la réalisation, la personne responsable du paiement des frais d'organisation ainsi que les personnes qui exécuteront l'abattage.]

$\S 6$.

1. Umowa może być rozwiązana przed upływem terminu, na który została zawarta, w drodze porozumienia Wydzierżawiającego i Dzierżawcy. 


\section{Comparative Legilinguistics 17/2014}

[1. Le présent contrat de bail de chasse peut être résilié avant le terme par accord amiable entre le bailleur et le preneur.]

2. Wydzierżawiający może rozwiązać umowę dzierżawną przed upływem terminu, na jaki została zawarta, za trzymiesięcznym wypowiedzeniem w przypadku nieprzestrzegania przez dzierżawcę zasad prowadzenia racjonalnej gospodarki łowieckiej oraz warunków zawartych w umowie.

[2. Si le bailleur ne respecte pas les principes de la gestion cynégétique rationnelle ainsi que les dispositions du présent contrat le bailleur peut résilier le présent contrat avant son terme, avec un préavis de trois mois.]

3. Umowa dzierżawna ulega rozwiązaniu w przypadku:

1) wyłączenia obwodu łowieckiego z wydzierżawienia,

2) rozwiązania koła łowieckiego.

[3. Le bail de chasse est résilié dans les cas suivants :

1) l'exclusion du terrain de chasse du bail de chasse,

2) la dissolution du club de chasse.]

$\S 7$.

Dzierżawiony obwód łowiecki ani jego część nie może być oddawany osobie trzeciej do bezpłatnego używania ani poddzierżawiany.

[Le terrain de chasse loué ni aucune de sa partie ne peut être mis à la disposition des tiers à titre gratuit ni sous-loué.]

$\S 8$.

Zmiany umowy wymagają formy pisemnej pod rygorem nieważności.

[Toute modification du présent contrat exigera la forme écrite à peine de nullité.] $\S 9$.

Umowa została sporządzona w 5 egzemplarzach, z których po jednym otrzymują:

1. Wydzierżawiający,

2. Dzierżawca,

3. Gmina Stupno

4. Nadleśnictwo Konin

[Fait en 5 exemplaires, dont un pour :

1. le bailleur,

2. le preneur,

3. la commune Słupno,

4. 1'administration des forêts de Konin.]

DZIERŻAWCA

[PRENEUR]

WYDZIERŻAWIAJĄCY

[BAILLEUR]

Przykład 2. Tłumaczenie francuskiej umowy bail de chasse na język polski

Commune de CRÉCY-AU-MONT

4, Place Bouchard 02380 CRÉCY-AU-MONT

Tel/fax 03.23.52.43.65

Département de l'Aisne

Arrondissement de LAON

Canton de COUCY-LE-CHATEAU

[Gmina CRÉCY-AU-MONT

4, Place Bouchard 02380 CRÉCY-AU-MONT

Tel/fax 03.23.52.43.65

SLOT: Departament Aisine ; TLOT : Powiat Aisine

Okręg LAON 


\section{CONTRAT DE BAIL-CHASSE \\ [UMOWA DZIERŻAWY OBWODU LOWIECKIEGO]}

Entre les soussignés :

La Commune de CRECY-AU-MONT, Mairie de CRECY-AU-MONT 4 place Bouchard - 02380 CRECY-AU-MONT - représentée aux fins des présentes par son Maire, Monsieur....

Dénommé ci-après le bailleur,

D'une part

Et l'Association des Chasseurs de CRECY-AU-MONT - représenté par son Président, Monsieur xxxxxxxx - Rue - 02380 CRECY-AU-MONT

Dénommé ci-après le preneur,

[Między niżej podpisanymi

D'autre part

Gminą CRECY-AU-MONT, Merostwo CRECY-AU-MONT, z siedzibą Plac Bouchard 4 - 02380 CRECY-AU-MONT - reprezentowaną przez Mera, Pana............

zwanym w dalszej części umowy wydzierżawiającym, a

Zrzeszeniem myśliwych CRECY-AU-MONT - reprezentowanym przez Prezesa, ..............., ul......... - 02380 CRECY-AU-MONT,

zwanym w dalszej części umowy dzierżawcą]

Il a été exposé ce qui suit :

[Została zawarta umowa o następującej treści:]

Le bailleur ci-dessus désigné loue à bail à l'Association des chasseurs de CRECYAU-MONT, représentée par Monsieur....qui l'accepte le droit de chasser en Forêt Communale de CRECY-AU-MONT dont le preneur déclare bien connaître les limites.

[Wyżej wymieniony wydzierżawiający oddaje w dzierżawę na rzecz Zrzeszenia Myśliwych CRECY-AU-MONT, reprezentowanego przez Pana ..........., który akceptuje prawo do polowania na terenie lasów gminy CRECY-AU-MONT i oświadcza, że znane mu są ich granice.]

ARTICLE 1 - Consistance du lot

[Art. 1 - Zróżnicowanie obwodu łowieckiego]

Le lot de chasse est constitué par les parcelles cadastrales suivantes :

[W skład obwodu łowieckiego wchodzą następujące działki wpisane do publicznego rejestru gruntów:]

$\begin{array}{llll}\mathrm{AB} & 174 & \text { LES PRES DE BETHANCOURT } & 459 \\ \mathrm{AB} & 175 & \text { LES PRES DE BETHANCOURT } & 7520 \\ \mathrm{AB} & 176 & \text { LES PRES DE BETHANCOURT } & 149 \\ \mathrm{AB} & 177 & \text { LES PRES DE BETHANCOURT } & 11061 \\ \mathrm{AC} & 61 & \text { LA MONTAGNE } & 985 \\ \mathrm{AC} & 62 & \text { LA MONTAGNE } & 685 \\ \mathrm{AC} & 63 & \text { LA MONTAGNE } & 423 \\ \mathrm{AC} & 65 & \text { LA MONTAGNE } & 662 \\ \mathrm{AC} & 70 & \text { LA RUE DES VACHES } & 300\end{array}$




$\begin{array}{llll}\mathrm{AC} & 260 & \text { LA PATURELLE } & 380 \\ \mathrm{AE} & 75 & \text { PATURE DU CATILLON } & 3085 \\ \mathrm{AE} & 76 & \text { PATURE DU CATILLON } & 5708 \\ \mathrm{AE} & 77 & \text { PATURE DU CATILLON } & 9820\end{array}$

La surface du lot est de 41 ha 78 ca 48 a.

[Powierzchnia obwodu łowieckiego wynosi 41 ha $78 \mathrm{~m}^{2} 48$ a]

ARTICLE 2 - Durée.

[Art. 2 - Czas trwania umowy]

Le droit de chasse est consenti pour une durée de 3 années qui commencera à partir du 01 novembre 2006 jusqu'au 31 octobre 2009 et renouvelable par tacite reconduction tous les 3 ans à moins que l'une ou l'autre des parties ne résilie le bail par lettre recommandée avec accusé de réception au mois six mois avant la date d'échéance. En cas de dissolution de l'Association des Chasseurs de CRECY-AU-MONT, le bail est résilié d'office.

[Przyznaje się prawo polowania na okres 3 lat począwszy od 1 listopada 2006 roku do 31 października 2009 roku z możliwością dorozumianego przedłużenia umowy co 3 lata, chyba że jedna ze stron rozwiąże umowę listem poleconym za potwierdzeniem odbioru co najmniej na 6 miesięcy przed upływem terminu na jaki umowa została zawarta. W razie rozwiązania Zrzeszenia Myśliwych CRECYAU-MONT dzierżawa ulega automatycznie rozwiązaniu.]

ARTICLE 3 - Rendement de la chasse - Modification de consistance. [Art. 3 - Efektywność polowania - Zmiana zróżnicowania obwodu lowieckiego]

Le rendement de la chasse n'est pas garanti. Il ne sera accordé aucune réduction de prix du bail:

$1^{\circ}$ ) Pour défaut de mesure de l'étendue du lot

$2^{\circ}$ ) En cas de diminution de gibier pour quelque cause que ce soit

$3^{\circ}$ ) En cas d'interdiction provisoire du droit de chasse par les autorités administratives

[Efektywność polowania nie jest gwarantowana. Czynsz dzierżawny nie będzie podlegać obniżeniu w przypadku:

1) braku pomiaru zasięgu danego obwodu łowieckiego

2) zmniejszenia się ilości zwierzyny z jakiejkolwiek przyczyny

3) wprowadzenia przez organy władzy administracyjnej tymczasowego zakazu wykonywania prawa polowania.]

Si la destination du lot est modifiée par suite l'aliénation, de défrichement, d'échange etc.... le bailleur ne devra aucune indemnité au preneur, le bail sera maintenu et le prix de location sera révisé proportionnellement à l'étendue qui aura été distraite ou ajoutée. Si les modifications portent sur $25 \%$ ou plus de la surface totale, le bail pourra être résilié purement et simplement à la demande de l'une ou l'autre des parties.

[Jeśli przeznaczenie obwodu łowieckiego ulegnie zmianie w wyniku przeniesienia prawa własności, karczowania, zamiany, itd ..., wydzierżawiający nie jest zobowiązany wypłacić żadnego odszkodowania dzierżawcy, dzierżawa jest kontynuowana, a wysokość czynszu dzierżawnego zmieni się w zależności od zasięgu powierzchni wyłączonej lub dołączonej do danego obwodu łowieckiego. Jeśli zmiany objęły obszar $25 \%$ całej powierzchni obwodu, bądź większy, dzierżawa może zostać rozwiązana przez każdą ze stron.] 


\section{ARTCLE 4 - Servitudes}

\section{[Art. 4 - Slużebności]}

Le preneur ne pourra réclamer aucune indemnité, ni demander aucune révision de prix au propriétaire en raison de trouble que pourraient apporter à leur jouissance les exploitations, les travaux d'entretien ou d'amélioration du lot consenti, notamment par plantations artificielles.

Le preneur aura le droit :

- d'utiliser pour cultures à gibier les terres précitées

- d'aménager des points d'eau et des sentiers de piégeage

- de tracer dans les bois tous sentiers d'assommoirs, d'agrainage et layons qu'il jugera utiles.

[Dzierżawca nie ma prawa żądać od właściciela odszkodowania, ani zmiany wysokości czynszu z powodu zakłóceń w korzystaniu $\mathrm{z}$ obwodu wynikających $\mathrm{z}$ zagospodarowywania terenu, prac związanych z utrzymaniem lub ulepszaniem przyznanego obwodu łowieckiego, a zwłaszcza z zakładaniem sztucznych upraw.

Dzierżawca ma prawo:

- użytkować wyżej cytowane działki łowieckie w celu uprawy poletek dla zwierzyny

- zagospodarowywać ujścia wodne i ścieżki pułapek

- wyznaczać w lasach ścieżki potrzasków, pasy zaporowe i wytyczać linie działowe, jeśli uzna to za stosowne]

L'Exploitation des bois (curage de fossés, plantations des parcelles exploitées, gyrobroyage, élagage et traitement des parcelles), se fera par des entreprises habilitées à réaliser ces travaux sous couvert de l'O.N.F du 01 mars au 31 août. Exceptionnellement, un accord entre bailleur et locataire peut être pris pour le nettoyage des parcelles suite à l'exploitation des bois.

[Zagospodarowanie lasów (oczyszczanie rowów, zalesianie użytkowanych działek łowieckich, kontrola i usuwanie zbędnych zarośli, okrzesywanie zbytecznych gałęzi i obrabianie działek) jest wykonywane przez przedsiębiorstwa specjalizujące się w tym zakresie pod nadzorem O.N.F (Office National des Forêts - instytucja zarządzająca lasami państwowymi we Francji, odpowiednik polskiego Państwowego Gospodarstwa Leśnego Lasy Państwowe) od 1 marca do 31 sierpnia. Wyjątkowo, wydzierżawiający i dzierżawca mogą ustalić między sobą kwestie porządkowania działek łowieckich w związku z zagospodarowywaniem lasów.]

\section{ARTICLE 5 - Prix du bail \\ [Art. 5 - Wysokość czynszu dzierżawnego]}

Le présent bail de chasse est consenti moyennant un loyer annuel de ...€ de l'hectare (...euros) multiplié par l'indice de fermage augmenté de 10\% de charge chaque année.

[Za opisaną dzierżawę obwodu łowieckiego przysługuje roczny czynsz w wysokości ...... $€$ za hektar (....euro) pomnożony przez współczynnik czynszu dzierżawnego podwyższony o $10 \%$ nakładów poniesionych każdego roku.]

Il sera payé en une seul fois, chaque année, d'avance, avant le $1^{\mathrm{ER}}$ novembre à la Caisse de Monsieur le Trésorier Principal de COUCY-LE-CHATEAU, Percepteur.

[Czynsz płatny jest jednorazowo, każdego roku z góry w terminie do 1 listopada do Kasy Głównego Skarbnika gminy COUCY-LE-CHATEAU, Poborcy.] 


\section{Comparative Legilinguistics 17/2014}

En cas de retard de paiement, les intérêts de prix de location courront du plein droit et à partir du jour où le paiement aurait dû être effectué au taux de $10 \%$ l'an. Pour le calcul des intérêts les fractions de mois seront négligées.

[W razie zwłoki w uiszczaniu czynszu, odsetki od kwoty czynszu naliczane są z mocy prawa począwszy od dnia, w którym czynsz powinien być uiszczony i wynoszą 10\% na rok. Przy obliczaniu wysokości odsetek nie są brane pod uwagę raty miesięczne.]

En cas de non-paiement d'une année par le preneur, après une mise en demeure adressée par Le Maire sur l'avis du Percepteur, le preneur sera déchu de tous ses droits de bail.

[W razie zalegania dzierżawcy z zapłatą czynszu dzierżawnego za okres jednego roku, po uprzednim wezwaniu go do zapłaty wystosowanym przez Mera i po zasięgnięciu opinii Poborcy, dzierżawca traci wszelkie prawa do dzierżawy.]

Il pourra en outre être intenté des poursuites contre le preneur en remboursement des termes échus et pour paiement de la différence entre le prix de son bail et celui de la réadjudication, pour les termes qui restent à courir sans qu'il puisse être réclamé par eux l'excédent s'il y en a. En aucun cas le preneur qui aura été privé du droit d'obtenir un permis de chasse par application des articles 366 bis, 367, 368 et 369 du Code Rural, ne sera fondé à demander la résiliation de son bail, ou une diminution de prix.

Le preneur s'engage à payer toutes les taxes qui viendraient s'ajouter au prix de la location.

[ Przeciwko dzierżawcy może zostać wszczęte postępowanie o zapłatę zaległych należności oraz o zapłatę różnicy między kwotą jego czynszu dzierżawnego, a kwotą zaoferowaną przez innego dzierżawcę w ponownym przetargu, za czas pozostały do końca umowy, bez możliwości żądania zwrotu nadwyżki, jeśli taka zaistnieje. W żadnym razie dzierżawca, który zostanie pozbawiony prawa do uzyskania pozwolenia na polowanie na skutek zastosowania artykułów 366 bis, 367, 368 i 369 Kodeksu Rolnego, nie będzie mieć podstaw do wystąpienia z żądaniem rozwiązania umowy dzierżawy lub obniżenia czynszu.

Dzierżawca zobowiązuje się uiszczać wszystkie podatki doliczane do czynszu dzierżawnego.]

EXPLOITATION ET POLICE DE LA CHASSE

[GOSPODARKA I STRAŻ LOWIECKA]

ARTICLE 6 - Surveillance de la chasse.

[Art. 6 - Nadzór polowania]

L'Association des Chasseurs de CRECY-AU-MONT devra se conformer aux conditions générales de la chasse de la Fédération des Chasseurs de l'Aisne.

[Zrzeszenie Myśliwych CRECY-AU-MONT jest zobowiązane przestrzegać ogólnych warunków polowania Federacji Myśliwych SLOT: departamentu Aisne, TLOT: powiatu Aisne.]

ARTICLE 7 - Jour de chasse - Nombre de fusils - Mesure de sécurité Règlement intérieur

[Art. 7 - Dzień polowania - Liczba jednostek broni - Środki ostrożności Regulamin wewnętrzny]

L'Association des Chasseurs de CRECY-AU-MONT est constituée de propriétaires ou locataires de CRECY-AU-MONT. Le preneur aura le droit de s'adjoindre telle personne que bon lui semblera (chasseurs extérieurs ou invités). 
Le nombre de nombre de fusils sera limité conformément aux statuts et règlement intérieur votées en Assemblée Générale.

[Zrzeszenie Myśliwych CRECY-AU-MONT zrzesza właścicieli i dzierżawców gminy CRECY-AU-MONT. Dzierżawca ma prawo do wyboru dowolnej osoby na swojego pomocnika (myśliwego $\mathrm{z}$ zewnątrz lub osoby zaproszonej). Liczba jednostek broni jest ograniczona zgodnie ze statutem i regulaminem wewnętrznym ustanowionym przez Walne Zgromadzenie Zrzeszenia.]

Les jours de chasse seront désignés par les statuts et règlement intérieur.

[Okresy polowań są określone w statucie i regulaminie wewnętrznym.]

Quinze jours avant l'ouverture de la saison de chasse, le preneur devra remettre en Mairie le calendrier des jours de chasse.

[Piętnaście dni przed rozpoczęciem sezonu łowieckiego, dzierżawca przedstawia w SLOT: Merostwie / TLOT: Urzędzie Gminy kalendarz polowań.]

Le locataire doit prendre toutes les précautions propres à éviter les accidents à l'occasion des actions de chasse, tant à l'égard des chasseurs, rabatteurs, ... (notamment en imposant aux traqueurs ou conducteurs de chiens de porter des vêtements de couleur vive ou des baudriers fluorescents, en recommandant aux chasseurs postés de porter des brassards ou casquettes fluorescents, ainsi qu'en s'assurant que chaque tireur a bien reçu, contre récépissé, un document écrit rappelant les principales consignes de sécurité ainsi que toutes les règles d'annonces). Il devra, au besoin mettre en place une signalisation visant à avertir et déconseiller temporairement le passage sur les routes forestières non ouvertes à la circulation publique à leurs entrées et aux principaux carrefours.

[Dzierżawca jest zobowiązany powziąć wszelkie środki ostrożności w celu zapobieżenia wypadkom przy wykonywaniu polowania, zarówno wobec myśliwych, naganiaczy ....(zwłaszcza zobowiązując naganiaczy lub prowadzących psy do noszenia ubrań w jaskrawych kolorach lub pasków fluorescencyjnych, zalecając myśliwym na stanowiskach noszenie opasek lub czapek fluorescencyjnych, jak również poprzez upewnienie się, że każdy strzelec otrzymał, za potwierdzeniem odbioru, pismo przypominające o podstawowych zasadach bezpieczeństwa, jak również pozostałe wytyczne). Dzierżawca powinien ponadto, jeśli zajdzie taka potrzeba wprowadzić oznaczenia na wjazdach oraz skrzyżowaniach dróg leśnych zamkniętych dla ruchu publicznego, mające na celu tymczasowo ostrzegać i odradzać korzystanie z tych dróg.]

Par ailleurs, sur les routes ouvertes à la circulation publique ainsi que sur les itinéraires balisés, le locataire de chasse à tir sera tenu d'installer chaque jour de chasse des panneaux d'information signalant une opération de chasse à tir en cours. Cette signalisation doit impérativement être enlevée à la fin de chaque journée ou la journée de chasse.

[Na drogach otwartych dla ruchu publicznego, jak również na szlakach wytyczonych, dzierżawca obwodu łowieckiego zobowiązany jest do umieszczania każdego dnia polowania tablic informujących o trwającym polowaniu. Oznakowanie to musi być obowiązkowo usunięte na koniec każdego dnia lub w dniu polowania.]

Le locataire sera tenu de remettre au Maire le règlement intérieur de son association de chasse et les statuts de sa Société conformes aux lois actuelles approuvé par la Préfecture. Il sera tenu également de remettre au Maire, la liste de ses sociétaires. 


\section{Comparative Legilinguistics 17/2014}

[Dzierżawca zobowiązuje się do przedstawienia SLOT: Merowi / TLOT: Wójtowi/Burmistrzowi/Prezydentowi miasta regulaminu wewnętrznego zrzeszenia łowieckiego lub statutu spółki, zgodnego $\mathrm{z}$ obowiązującymi regulacjami przyjętymi przez SLOT: Prefekturę / TLOT: Urząd gminy. Jest zobowiązany również do przedstawienia Merowi listy wspólników.]

\section{ARTICLE 8 - Destruction des nuisibles.}

\section{[Art. 8 - Eliminowanie gatunków szkodliwych]}

Dans le cas où la surabondance d'animaux nuisibles serait de nature à porter préjudice au gibier, aux cultures ou aux peuplement forestiers, le locataire pourrait mettre en demeure le preneur de procéder à leur destruction dans un délai déterminé. Le preneur pourra engager des gardes et piégeurs particuliers.

[W razie gdyby nadmiar gatunków zwierząt szkodliwych zaczął działać na szkodę innej zwierzyny, upraw lub drzewostanu, wydzierżawiający może wezwać dzierżawcę do ich wyeliminowania w określonym terminie. Dzierżawca może zatrudnić strażników oraz myśliwych do odłowu gatunków uważanych za szkodniki.]

Faute par celui-ci de satisfaire à cette mise en demeure, elle souffrirait les battues qui pourraient être ordonnées.

[W razie gdyby dzierżawca nie zastosował się do wspomnianego wezwania, zwierzyna ta może zostać odstrzelona w zarządzonym polowaniu zbiorowym.]

\section{RESPONSABILITE : \\ [ODPOWIEDZIALNOŚĆ] :}

\section{ARTICLE 9 - Dommages.}

\section{[Art. 9-Szkody]}

Le preneur sera civilement responsable de tous dommages causés aux tiers et à la commune de CRECY-AU-MONT, au cours ou à l'occasion de l'exercice du droit de chasse par lui-même, ses actionnaires, associés, sociétaires, préposés invités et de manière générale par tout personne autorisée par lui à chasser en ou hors de la présence de ses membres ainsi que par leur animaux.

[Dzierżawca ponosi odpowiedzialność cywilną za wszelkie szkody wyrządzone osobom trzecim i gminie CRECY-AU-MONT w trakcie lub przy okazji korzystania z prawa do polowania, przez niego, jego akcjonariuszy, zrzeszonych członków, wspólników, zaproszonych przełożonych i ogólnie przez każdą osobę, która uzyskała jego zgodę na polowanie, także pod nieobecność członków zrzeszenia, w tym również za szkody wyrządzone przez jego zwierzynę.]

A ce titre et à peine de résiliation de la location, il devra dans les 15 jours de la conclusion du contrat :

- s'assurer au moins pour les dommages corporels et pour une somme illimitée,

- déposer la police d'assurance entre les mains du Maire à qui il présentera ultérieurement les quittances de prime au fur à mesure des échéances.

[Z tego tytułu, pod rygorem rozwiązania niniejszej umowy dzierżawy, dzierżawca jest zobowiązany w ciągu 15 dni od jej zawarcia:

- ubezpieczyć się co najmniej od szkód powstałych wskutek uszkodzenia ciała na nieograniczoną kwotę

- złożyć na ręce Merowi polisę ubezpieczeniową SLOT: Merowi / TLOT: Wójtowi, któremu uprzednio przedstawi potwierdzenie zapłaty składek ubezpieczeniowych w terminach ich wymagalności.] 
La commune de CRECY-AU-MONT sera en ce qui la concerne subrogée dans tous les droits de l'assuré en cas de dommage subi par elle et elle pourra notifier à la Compagnie, aux frais de ce dernier, tous les actes nécessaires pour faire produire à cette subrogation son effet.

[Gmina CRECY-AU-MONT wstępuje, w zakresie który jej dotyczy, we wszystkie prawa ubezpieczonego, w przypadku poniesienia szkody przez gminę. Może ona powiadomić Towarzystwo Ubezpieczeniowe, na koszt ubezpieczonego, o wszystkich czynnościach koniecznych w celu realizacji wstąpienia w jego prawa.]

\section{ARTICLE 10 - Charges. \\ [Art. 10 Obciążenia]}

L'entretien annuel des lignes et sommières, nécessaire pour permettre un tir dans des conditions de sécurité optimales, est à la charge du locataire. La nature et l'intensité des travaux à effectuer devront être concertées entre le locataire et l'agent O.N.F.

[Całoroczne utrzymanie linii i stanowisk, koniecznych do zachowania optymalnych warunków bezpieczeństwa podczas strzelania jest obowiązkiem dzierżawcy. Rodzaj i intensywność prac koniecznych do wykonania powinny być uzgodnione pomiędzy dzierżawcą a urzędnikiem O.N.F (Office National des Forêts - instytucja zarządzająca lasami państwowymi we Francji, odpowiednik Państwowego Gospodarstwa Leśnego Lasy Państwowe w Polsce).]

\section{ARTICLE 11 - Poursuites.}

\section{[Art. 11 - Ściganie przestępstw]}

Sous réserve du droit de transaction appartenant à l'administration, les infractions aux lois et règlements, ainsi qu'aux dispositions du cahier des charges, de la part du preneur ou des personnes dont il est accompagné, ou qu'il a autorisées à chasser, et des délits de chasse commis par les personnes sans titre, dans les lots affermés, seront poursuivies correctionnellement sauf à la partie lésée, et après le Ministère Public lui aura donné au procès-verbal, à intervenir pour réclamer des dommages et intérêts auxquels elle aurait droit.

[Z zastrzeżeniem prawa do zawarcia ugody przysługującego organom administracji, naruszenia ustaw i rozporządzeń, jak również pogwałcenie przepisów zawartych w "cahier de charges”, (przyp. tlum.: dost. „w zeszycie obciążen', czyli dokumencie zawierająym warunki dotyczace dzierżawienia obwodów towieckich oraz wykonywania polowań) oraz wszelkie występki popełnione podczas polowania na terenie wydzierżawionych obwodów przez dzierżawcę, towarzyszące mu osoby lub też osoby, którym udzielił zgody na polowanie będą ścigane w postępowaniu karnym, chyba że strona poszkodowana, za zgodą Prokuratora sama będzie dochodzić przysługującego jej odszkodowania.]

Fait à CRECY-AU-MONT, le $1^{\mathrm{er}}$ novembre 2006 en 5 exemplaires.

[Sporządzono w CRECY-AU-MONT, dnia 1 listopada 2006 roku w 5 egzemplarzach]

L'Association des Chasseurs de CRECY-AU-MONT représentée par Monsieur XX

[Stowarzyszenie Myśliwych CRECY-AU-MONT, reprezentowane przez Pana $\mathrm{XX}]$ 
Le MAIRE

$\mathrm{XX}$

[MER]

\section{Podsumowanie}

Tłumaczenie i przeprowadzona analiza umów pozwala stwierdzić, że zarówno umowy polskie jak i francuskie wykazują pewne podobieństwa jak i różnice ma poziomie makro- i mikrostruktury tych tekstów, co ma istotne znaczenie z punktu widzenia przekładu. Zgodnie z klasyfikacją Wróblewskiego (1948) rozwiniętą przez Zielińskiego (1999) teksty analizowanych umów sformułowane są w języku prawniczym. Język ten wyróżnia się specyficzną terminologią, swoistymi strukturami gramatycznymi, składniowymi oraz cechami stylistycznymi. Język ten charakteryzuje się ponadto dyrektywnością, bezosobowością, precyzyjnością i standardowością (Wojtak 1993, 147).

Zarówno polskie jak i francuskie umowy, zawierają zarówno powtarzalne sformułowania, które organizują tekst umowy i wprowadzają poszczególne jej części, jak również standardowe klauzule umowne. Przykładowo, formuły wprowadzające nazwy stron umowy (zwanym dalej czy też dénommé ci-après) czy też formuły wprowadzające właściwą treść umowy (została zawarta umowa treści następującej lub w umowie francuskiej Il a été exposé ce qui suit) bądź też wyrażenia dotyczące ilości egzemplarzy (polskie umowa została sporządzona $w 5$ egzemplarzach czy francuskie Fait à ...en 5 exemplaires). Typowymi francuskimi i polskimi klauzulami są natomiast np.: klauzule dotyczące przedmiotu umowy, czasu obowiązywania i zakończenia umowy, klauzule określające wysokość i sposób płatności czynszu dzierżawnego, klauzule dotyczące egzemplarzy itp. Niektóre klauzule wystąpiły jednak tylko w umowach francuskich jak np.: klauzula dotycząca szkód łowieckich, klauzula dotycząca eliminowania gatunków szkodliwych czy też klauzula dotycząca szczegółowych warunków wykonywania polowania.

Powtarzalność i typowość wymienionych przykładowo elementów i sformułowań w polskich i francuskich umowach stanowi istotną informację dla tłumacza, który po zapoznaniu się z typowymi strukturami występującymi w języku źródłowym powinien zastąpić je odpowiadającymi im strukturami w języku docelowym. W efekcie pozwoli to na utworzenie tekstu odpowiadającego zasadom ekwiwalencji tekstowo-normatywnej i pragmatycznej, czyli tekstu zgodnego pod względem treści oraz zgodnego z konwencją języka umów w kulturze docelowej (por. Jopek-Bosiacka 2006).

Niemniej jednak, mimo wspomnianych podobieństw, między polską a francuską umową istnieją pewne znaczące różnice.

Umowa francuska jest znacznie dłuższa niż umowa polska. Jest ona bardziej rozbudowana w swojej treści, gdyż zawiera niekiedy różne postanowienia charakterystyczne dla danego rodzaju umowy.

Istotne różnice można również zaobserwować na poziomie gramatycznym tekstu. Zarówno w polskim jak i francuskim języku analizowanej umowy wystąpiły zasadnicze różnice związane $\mathrm{z}$ występowaniem w języku francuskim konstrukcji w stronie biernej, w zwłaszcza passif initial lub passif impersonnel, gdzie dosłowne tłumaczenie tych konstrukcji mogłoby doprowadzić do zaburzenia składni w języku 
polskim i brzmiałoby nienaturalnie np.: (Passif initial Il ne sera accordé aucune réduction du prix du bail, czyli dosł. Nie zostaje przyznana zniżka czynszu dzierżawnego zamiast thumaczenia w stronie czynnej Czynsz dzierżawny nie podlega obniżeniu).

Ponadto, leksyka obu rodzajów umów jest bardzo zróżnicowana i można w niej wyróżnić zarówno terminy języka prawa oraz słownictwa języka ogólnego, użyte w nim w znaczeniu ogólnym lub które nabiera specyficznego znaczenia w języku prawa. Licznie występują tu również terminy należące do innych dziedzin specjalistycznych, a zwłaszcza rolnictwa, leśnictwa oraz łowiectwa. Jest to leksyka, która niewątpliwie stanowi wyzwanie dla thumacza. Szczególnie trudne dla adeptów sztuki przekładu mogą się okazać terminy dotyczące łowiectwa i leśnictwa z umowy francuskiej typu: sentiers d'agrainage - pasy zaporowe, rabatteur - naganiacz, gyrobroyage - usuwanie zbędnych zarośli, élagage - okrzesywanie gałęzi itp. czy też umowy polskiej jak np.: strażnik towiecki - garde de chasse, odstrzat zastępczy - l'abattage supplémentaire, wytaczenie obwodu towieckiego - exclusion du lot de chasse. Problemy w stosowaniu powyższej terminologii mogą wynikać przykładowo ze zjawiska polisemii terminów (zarówno polisemii językowej jak i prawniczej ${ }^{13}$ ). W analizowanej umowie francuskiej w przypadku polisemii prawniczej, tłumacz musi znać znaczenia prawnicze często $\mathrm{z}$ różnych poddziedzin prawa. Problematyczne mogą okazać się tutaj terminy takie jak np.: affermage (1. wydzierżawienie; 2. dzierżawa; 3. czynsz dzierżawny), bailleur (1. wydzierżawiający; 2. wynajmujący), bail/location (1.najem; 2. dzierżawa / 1. najem; 2. dzierżawa), condition (1. warunek; 2. przesłanka), itp.

Aby uniknąć błędów tłumaczeniowych wynikających z polisemii należałoby przed thumaczeniem przeanalizować kontekst, w jakim terminy te występują. Znajomość instytucji prawnych również może być przydatna.

Inne trudności na poziomie leksykalnym, na które może natknąć się thumacz thumaczący umowę dzierżawy obwodu łowieckiego mogą wynikać ze zjawiska synonimii pozornej (por. Cornu 2005, 173-175). Synonimy te są trudne do rozróżnienia, mogą prowadzić do powstawania błędów rejestru w przekładzie. W umowach francuskich przykładowo często używane są terminy bail i location, które nie są pełnymi synonimami, i nie mogą być stosowane zamiennie. Zasadniczo terminu bail używa się $\mathrm{w}$ odniesieniu do nieruchomości, natomiast location do ruchomości, bądź nieruchomości umeblowanych. Zdarza się, że w języku prawniczym terminy te używane są zamiennie. Tłumaczenie tych terminów na język polski jest problematyczne, a ich stosowanie zależy od kontekstu. Dodatkowo obydwa terminy są polisemiczne i można je przetłumaczyć zarówno jako najem jak i dzierżawę.

Kolejną kwestią jest obecność w umowach zwrotów niedookreślonych znaczeniowo oraz nieostrych zakresowo prowadzących do zaburzenia precyzji i jednoznaczności tekstu prawnego (por. Jopek-Bosiacka 2006, 32). Przykładowe terminy polskie tego typu to: racjonalna gospodarka lowiecka - gestion cynégétique rationnelle, oraz wytaczenie obwodu - exclusion du lot de chasse. W umowie

\footnotetext{
${ }^{13} \mathrm{~W}$ obrębie polisemii Sourioux i Lerat $(1975,95)$ wyróżniają polisemię językową (polysémie linguistique) oraz prawniczą (polysémie juridique). Polisemia językowa dotyczy terminów posiadających różne znaczenia w języku ogólnym bądź specjalistycznym oraz w języku prawa. W przypadku polisemii prawniczej jeden termin posiada różne znaczenia w języku prawa i języku innej dziedziny, np.: rolnictwa, bądź też posiada kilka różnych znaczeń z dziedziny prawa.
} 


\section{Comparative Legilinguistics 17/2014}

francuskiej wystąpił termin tacite reconduction - tzw. dorozumiane (milczące, automatyczne) przedłużenie umowy

Poza wymienionymi cechami język umów cechuje także występowanie licznych konstrukcji bezosobowych, nominalizacja, standardowość i precyzyjność.

Nie ulega wątpliwości, że znajomość opisanych powyżej podobieństw i różnic na poziomie mikro- i makrostruktury tekstów umów zarówno w języku źródłowym, jak i docelowym zdecydowanie ułatwia proces przekładu.

Należy także przy tym zwrócić uwagę na istotne znaczenie tekstów paralelnych w procesie tłumaczenia umów dzierżawy, które stanowią cenne źródło ekwiwalentów konotacyjnych.

Podsumowując należy podkreślić, że zaprezentowane przykładowe umowy polska oraz francuska wraz $\mathrm{z}$ thumaczeniami stanowią jedynie propozycję thumaczenia i nie wyczerpują wszystkich możliwości, które ma do dyspozycji tłumacz - z pewnością istnieje szereg innych ewentualnych tłumaczeń, które również mogą być zastosowane w przekładzie zacytowanych umów dzierżawy obwodu łowieckiego.

\section{Bibliografia}

Cornu, Jean. 2005. Linguistique juridique. Paris: Editions Montchrestien. EJA Damasiewicz, Agnieszka, 2005. Najem lokalu użytkowego. Warszawa: LexisNexis.

Delisle, Jean, 2006. Terminologia ttumaczenia. Poznań: Wydawnictwo Naukowe UAM (przekład i adaptacja Teresa Tomaszkiewicz).

Jopek-Bosiacka, Barbara, 2006. Przekład prawny i sądowy. Warszawa: Wydawnictwo Naukowe PWN.

Kielar, Barbara, Zofia., Michałowska, Katarzyna. 1994. Umowa handlowa - angielskie i polskie wzorce tekstowe. W Lingua Legis. Nr 1. B.Z. Kielar, J. Lewandowski, J. Maliszewski, D. Kierzkowska, J. Poznański (red.), 6-11.

Kierzkowska, Danuta, 2002. Ttumaczenie prawnicze. Warszawa: Polskie Towarzystwo Tłumaczy Ekonomicznych, Prawniczych i Sądowych TEPIS.

Lizisowa, Maria, 2013. Metody badań języka prawnego wobec ontologicznej natury prawa. Matulewska A. (red.), W Comparative Legilinguistic. International Journal for Legal Communication. Volume 13/2013, 20-44. Poznań: Zakład Graficzny UAM.

Machowska, Aleksandra, 2008. Słownik terminologii prawniczej polsko-francuski. Kraków: Wolters Kluwer Polska Sp. Z o.o.

Olczyk, Magdalena, 2006. Najem lokalu mieszkalnego. Warszawa: LexisNexis.

Pieńkos, Elżbieta, Pieńkos, Jerzy, 1981. Słownik terminologii prawniczej i ekonomicznej francusko-polski. Warszawa: Wiedza Powszechna.

Sourioux, Jean-Pierre, Lerat, Pierre. 1975. Le langage du droit. Paris: Presses Universitaires de France.

Stec, Roman, 2009. Prawo towieckie. Wybrane aspekty prawnoporównawcze. Warszawa: Bellona SA.

Szachułowicz, Jan, 2002. Problematyka prawna dzierżawy obwodów łowieckich. W Przegląd sądowy $n r$ 4/2002. Warszawa: Wydawnictwo Prawnicze Lexis Nexis. 
Paulina Nowak-Korcz, Dzierżawa obwodu towieckiego w aspekcie translatologicznym

Vermeer, Hans, 1978. Ein Raahem für eine Allgemeine Transationstheorie. W Lebende Sprachen 3, 99-102.

Vermeer, Hans, 2001. Skopos and commission in Translational Action. W: The translation Studies Reader, L. Venuti, M. Baker (red.), 221-232. London/New York: Routlege.

Wojtak, Maria, 1993. Styl urzędowy. W: Encyklopedia kultury polskiej XX wieku. Tom 2.Wspótczesny język polski, Bartmiński J. (red.) Wrocław

Wróblewski, Bronisław, 1948. Język prawny i prawniczy. Kraków: Polska Akademia Umiejętności.

Zieliński, Maciej, 1999. Języki prawne i prawnicze. W: Polszczyzna 2000. Orędzie o stanie języka na przetomie tysiącleci, Pisarek W. (red.), 50-74. Kraków: Ośrodek Badań Prasoznawczych. Uniwersytet Jagielloński.

\section{Kodeksy}

1. Code civil (Kodeks Cywilny) (C. civ.) w brzmieniu obowiązującym $2013 \mathrm{r}$.

2. Code rural et de la pêche maritime (Kodeks Rolny i Rybołówstwa Morskiego) (C. rur.) w brzmieniu obowiązującym $2013 \mathrm{r}$. 